\section{What If Big E Evolution is True?}

\author{
Anjeanette Roberts \\ in Thinking about Evolution
}

https://doi.org/10.54739/dy2p

$\mathbf{M}$ y coauthors and I are evidentialists. We believe the scientific data supports a progressive creation model as well as, or better than, an evolutionary account-but what if we're wrong?

What if plausible evidential mechanisms and processes, backed by empirical data, fill in the significant gaps, clarify the muddy middle layer of mechanism, and cross all significant remaining hurdles? Does this leave Christians two choices: deny God's

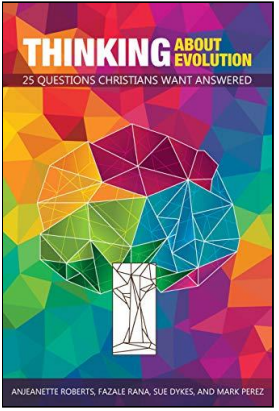
revelation in nature (or at least the possibility of any real integration of God's revelation in nature and the Bible) or flounder in an existential faith crisis? Well, those may be two options, but not by any means the only or best options if evolution with a big-E is true.

Since the time of evolution's earliest Darwinian versions, Christians committed to biblical authority and inerrancy have argued for God's creation through natural mechanisms. The conservative Reformed principal of Princeton Theological Seminary Benjamin Breckinridge Warfield (1851-1921) serves as a prominent example. Warfield was a staunch defender of the verbal plenary inspiration of Scripture and deeply committed to biblical inerrancy. Mark Noll articulates Warfield's position in Jesus Christ and the Life of the Mind: "Besides his openness toward evolution...Warfield was also the ablest modern defender of the theologically conservative belief in the inerrancy of the Bible." ${ }^{1}$ Noll continues:
This chapter is from Thinking About Evolution, a book published one year ago. The authors are progressive creationists at Reasons to Believe, who agree the Earth is old, but are skeptical of macroevolution. Still, they explain in this chapter what they would do if evolution were true.

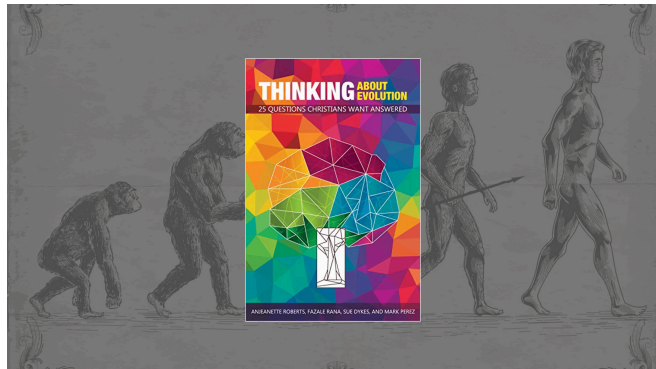

While he defended biblical inerrancy,

Warfield was also a cautious,

discriminating, but entirely candid

proponent of the possibility that evolution

might offer the best way to understand the

natural history of earth and of humankind.

On this score his views place him with

more recent thinkers who maintain

ancient trust in the Bible while also

affirming the modern scientific enterprise

and mainstream scientific conclusions.

Warfield did not simply assert these two

views randomly, but he sustained them

learnedly, as coordinate arguments. ${ }^{2}$

As Warfield did in his day, there are many faithful Christians today who confess Christ as Lord, hold the Bible as the authoritative Word of God, and believe in real miraculous events (e.g., Jesus's resurrection and the virgin birth) while also holding that God used the initial conditions he established at the creation along with evolutionary processes to accomplish his purposes for life's biological history on Earth. We call many of these scientists, with whom we disagree, friends. Many folks at Peaceful Science, BioLogos, the Discovery Institute, and the Faraday Institute for Science and Religion interpret the scientific evidence differently than we do at Reasons to Believe. Nevertheless, we embrace them as brothers and sisters in Christ.

After all, it is not one's view of origins that determines a person's Christian status. Scripture tells us it's not enough even to know the truth about God's existence, for even the demons know this truth and tremble (James 2:19). It matters whether we have a life transformed by and reconciled with God or not. It's about what we do with Jesus. Through God's revelation in nature and the Scriptures, we are invited to "taste and see that the Lord is good" (Psalm 34:8). We are called to recognize God's power, glory, and provision and our insufficiency and need to receive God's provision in Jesus for our reconciliation and restoration. We must be born again of the Spirit. In other words, we must have a real encounter with the risen Lord Jesus. This is the hallmark of being in Christ and the litmus of Christian orthodoxy, as is demonstrating love for one another as Christ did and commanded us to do (John 13:35).

As Noll points out, Warfield did not assert his two views (of God's activity through evolution and the inerrancy of Scripture) randomly, but “learnedly, as coordinate arguments." Warfield's approach continues today as many devoted Christ followers are doing hard, 
scholarly work together to advance the doctrine of creation in dialogue with scientists, theologians, and biblical scholars.

Included in these conversations are discussions about how an evolutionary paradigm of biological origins and biblical Christianity might be reconciled. At the time this book is published there will have been five meetings, one every summer since 2016, where biblical scholars, pastors, theologians, and scientists have come together to wrestle with the best ways to assess or accomplish this. These conferences are part of a larger effort known as the Creation Project at the Carl F. H. Henry Center for Theological Understanding. ${ }^{3}$ Dr. Rana and I have been privileged to participate each year. Much work with scholars in dialogue goes on between the conferences as well. Initiatives such as the Creation Project are and will be critical for the Christian community as theological challenges, such as those raised in chapter 5 , are continually engaged.

One significant work, facilitated by these and additional dialogues, is the emergence of a genealogical model of human origins ${ }^{4}$ that aligns with either a sequential or independent rendering of the creation accounts in Genesis 1-2 and that is in line with the range of faithful biblical exegesis. This model, championed by computational biologist and physician S. Joshua Swamidass, comports well with the genealogical emphasis in Genesis and throughout the Scriptures, as well as the de

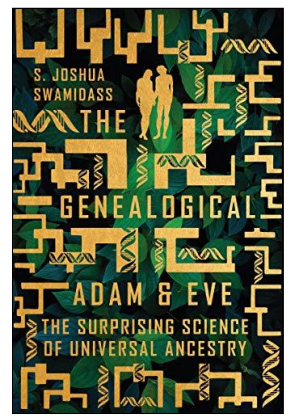
novo creation of Adam and Eve. It is arguably a nontraditional interpretation, but it lays a foundation for faithful interpretations that, rightly handled, pose no threat to the central tenets of biblical Christianity. In fact, it provides a way for biblical interpretations of a historical Adam and Eve-understood as universal, genealogical ancestors for all humanity living at the time of Christ and today-to be reconciled with mainstream evolutionary science.

If at some point in the future, the scientific evidence shows that evolutionary mechanisms are the mechanisms of God's creation, then interpretive models such as the one above will fill a needed space in biblical Christian thought. Meanwhile, for those who believe that evolutionary mechanisms have already attained sufficient evidentiary support, the fruits of this model and the laboring together as Christian scholars is already vitally important.

At this point, it is critical to realize and remind ourselves that Christianity is not a monolithic faith. It has existed in diverse forms across centuries and cultures. Orthodox, Catholic, and Protestant manifestations of Christ followers attest to this wide diversity. The apostle Paul shows us that even in early Christianity there were significant differences regarding nonessential details (e.g., Romans 14 and Ephesians 4:1-6). But he also emphasized that some details are essential and differences in those could impede the gospel and lead to something other than Christianity.

Paul abandoned unnecessary traditions for the sake of becoming as close to his audience as he could to bring the central message of salvation to as many as possible (1 Corinthians 9:19-23).

Christ died for our sins that we might be made new and reconciled to God (1 Corinthians 15:3-4 and 2 Corinthians 5:14-21). Certainly, this is the one nonnegotiable, the Cornerstone: who do you say that Christ is? Have you acknowledged the truth of his claim as Lord of all by surrendering your life to his lordship?

As we keep Christ at the center and follow the evidence where it leads, we can remain confident that we have nothing to fear from the truth. All truth is God's truth and his revelation rightly understood and interpreted will be consistent and beautiful and lead to his glory and praise. If evolution is the mechanism of God's creation, then the grounds for his glory and praise are not diminished. A 2017 song by Hillsong UNITED demonstrates this beautifully:

God of Creation...

You don't speak in vain

No syllable empty or void.

For once You have spoken

All nature and science

Follow the sound of Your voice.

And as You speak

A hundred billion creatures catch Your breath

Evolving in pursuit of what You said.

If it all reveals Your nature so will I. ${ }^{5}$

\section{In the End}

We are not progressive creationists because we think theistic evolution/evolutionary creation is a nonviable theological position or because it pushes God to the background. We are progressive creationists because we think the scientific data fits best with this position. Considering evolution's continual failure to account for major transitions and human uniqueness, we find no convincing reasons why it should be adopted over a progressive creation understanding of God's intimate and continual interaction with his creation in providential and revelatory ways.

Many suggest that in assuming our position we err regarding modern science in ways like the err of the church in the times of Galileo. We disagree. We stand firm on grounds that Galileo would hold as well. His statements suggest reexamination of the meaning of Scripture when faced with "natural phenomenon which is placed before our eyes by sensory experience or proved by necessary demonstrations." This is exactly what we wait and call for-necessary demonstrations.

I think that in disputes about natural phenomena one must begin not with the authority of scriptural passages, but with sensory experiences and necessary demonstration. For the Holy Scripture and nature derive equally from the Godhead. .. God reveals Himself to us no less excellently in the effects of nature than in the sacred words of Scripture ... and so it seems that a natural phenomenon which is placed before our eyes by sensory experience or proved by necessary demonstrations should not be called into question, let alone condemned, on account of scriptural passages whose words appear to have a different meaning.

However, by this I do not wish to imply that one should not have the highest regard for passages of Holy Scripture; indeed, after becoming certain of some physical conclusions, we should use these as very appropriate aids to the correct interpretation of Scripture and to the investigation of the truths they must contain, for they are most true and agree with demonstrated truths....I do not think one has to believe that the same God who has given us senses, 
language, and intellect would want to set aside the use of these and give us by other means the information we can acquire with them, so that we would deny our senses and reason even in the case of those physical conclusions which are placed before our eyes and intellect by our sensory experiences or by necessary

demonstrations. ${ }^{6}$

Warfield's "commitment to harmonizing a sophisticated conservative theology and the most securely verified conclusions of modern science" ${ }^{7}$ arguably suggests that he would have stood with us, too. His approach reflects the approach that Reasons to Believe takes to integrating God's revelation in nature and Scripture.

As Christ followers and scholars who care deeply about pursuing truth in science and rightly handling the Word of truth, we acknowledge that we must have intellectual humility and a love for others, especially in areas of strong disagreement. It is important as we study and wrestle together to ask ourselves if we are doing kingdom work and following Christ faithfully in respect to loving others and pursuing truth. In regard to our study and scholarship, the perspective of Dominican Albert Robertson, OP, is helpful:

Study helps us to love God more deeply, and it does this by purifying our understanding of God. Sometimes as students this means that we have to give up on favourite analogies or metaphors for our understanding of God for ones which more accurately correspond to revelation, and this should draw us into a closer relationship to God, for knowledge and love share a common source and ultimate end in God. $^{8}$

Scripture, too, calls us to maintain unity in love. It is the way we treat one another that will show the world that Jesus is who he claimed to be. As we continue to ask questions and search for answers, perhaps this is the most important thing to keep in mind-this, and God's promise of blessing on peacemakers, who will be called the children of God.

\section{Discussion Questions}

1. What was theologian B. B. Warfield's position on the Bible and science? What can we learn from his example?

2. Evaluate the statement that "all truth is God's truth." Is this your position? Explain.

3. What does intellectual humility look like for anybody, regardless of education or experience?

\section{References}

1. Mark A. Noll, Jesus Christ and the Life of the Mind (Grand Rapids, MI: Eerdmans, 2011), 111.

2. Noll, Jesus Christ and the Life of the Mind, 111-12.

3. "Creation Project FAQ," Carl F. H. Henry Center for Theological Understanding, https://henrycenter.tiu.edu/evangelical-theologyand-the-doctrine-of-creation/creation-project-faq/.

4. S. Joshua Swamidass, The Genealogical Adam and Eve: The Surprising Science of Universal Ancestry (Downers Grove, IL: IVP Academic, 2019).
5. "So Will I (100 Billion X)," track 4 on Hillsong UNITED, Wonder, Capitol Christian Music Group, 2017.

6. Galileo Galilei, “Galileo's Letter to the Grand Duchess Christina (1615)" in The Essential Galileo, ed. and trans. Maurice A. Finocchiaro (New York: Hackett Publishing, 2008), 116-17.

7. Noll, Jesus Christ and the Life of the Mind, 112.

8. Br. Albert Robertson, OP, “Dominican Life: Study,” Godzdogz: The Blog of the Dominican Student Brothers at Blackfriars, Oxford, May 27, 2019, https://www.english.op.org/godzdogz/dominican-lifestudy/. 